\title{
The Effect of Products and Prices on Purchasing Decisions of Health Food
}

Arien Anjar Puspitosari Suharso

Kanjuruhan University of Malang, Indonesia arien@unikama.ac.id

\section{ABSTRACT}

This study aims to analyze and explain the effect of products and prices on purchasing decisions of health food in Malang both partially and simultaneously. The approach uses quantitativeexplanatory methods. The population is Malang City Consumer in Blimbing, Kedungkandang, Klojen, Lowokwaru and Sukun Subdistricts. The samples are 384 respondents. The collected data is analyzed by multiple linear regressions with SPSS software version 22. The study results are follows. First, products partially affect on purchase decision of health food. Second, the prices can improve purchase decision of health food. Third, the price becomes the determining factor in purchase decision of health food.

Keywords: product; price; purchase decision

| Received May 2020 | Accepted July 2020 | Available online August 2020 |

| DOI: http://dx.doi.org 10.18860/mec-j.v4i2.9209

\section{INTRODUCTION}

The food and beverage industry in the last five years has become the most important sector to contribute revenue for Indonesia. The food sector in Indonesia contributed to gross domestic income (GDP) of $7 \%$ and $28 \%$ from total output in manufacturing industry in 2015. Contributions from this sector provide the largest contribution to GDP, especially for non-oil sector. Prospects from food and beverage industry continue to show significant growth to reach $13.6 \%$ in 2013 (Sidjabat, 2015).

The Indonesia population grows rapidly along with level of urbanization. This affects the development of consumer market opportunities in the world by $56.20 \%$. The higher income contributes to greater demand for sources derived from calories at higher prices such as meat, fruit, vegetables and processed food products (Widarjono, 2012; Dewi, 2013; Sari, Prihartini, \& Brantas, 2014). This is also happened in the period $1961-2008$, the total calories of low value products such as flour derived from plant roots have been replaced by high value foods such as meat, fish / seafood, fruits, vegetables and vegetable oils (Widarjono, 2012; Santoso, 2011; Tangkudung, Kadir, \& Pateda, 2013). Consistent with this, the main focuses of Indonesian population are product, fitness and health factors for purchase decisions of health food.

Purchase decision of health food is a consumer behavior as the process a person in finding, buying, using, evaluating, and acting after consuming the products, services and 
ideas that are expected to meet their needs (Schiffman and Kanuk, 2004). One of them is health products as yogurt and bottled drinks as the most popular beverage in Indonesia, about 54.2\% (Roemling \& Qaim, 2013; Umberger et al., 2015). Therefore, the most important thing in purchase decision of food is to consider the product and price (Basu \& Wong, 2015; Defra, 2015; Umberger et al., 2015).

All products are valued for services they provide and the value derived from physical goods. It is not about the product itself, but also the services provided during consumption (Lovelock and Wirtz, 2011; Muzondo, 2016). Important product factors for customers are quality, brand, health \& environmental safety and taste (Indumathi and Dawood, 2016). Heryanto (2015) stated that product has an effect on purchase decision of health food. Prihatini and Edwar (2016) stated that partially the product has an effect on purchase decision of health food.

Prices have a significant relationship with purchase decision of health food (Othman et al., 2013). There is a possibility of a positive effect of food variations choice for diets and cheap food prices (Brandenburg, 2011; Studies, 2015; Waage et al., 2013). Several methods have been used to predict household food consumption and expenditure for food purchases (Umberger et al., 2015). Indahswari, Thaha, \& Syam (2013) showed that prices have a significant relationship with purchase decision of health food. Price becomes the dominant variable in purchasing decisions (Sudrajad and Andriani, 2015). Prihatini and Edwar (2016) stated that partially the price affect on purchase decision of health food.

This study aims to examine the effect of prices and products on purchase decision of health food. Therefore, the research motivation to examine the effect of products and prices on purchase decision of health food provides opportunities for research.

\section{THEORETICAL REVIEW}

\section{Product and Purchasing Decisions}

Product is offered goods to market to be noticed, obtained, used or consumed with aim to meet consumer needs (Armstrong and Keller, 2012). Lovelock and Wirtz (2011) suggested that all products are valued for services they provide. The value derived from physical goods is not from the product itself, but also the services provided during consumption (Muzondo, 2016). Schiffman and Kanuk (2004) defined consumer behavior as the process a person in finding, buying, using, evaluating, and acting after consuming the products, services and ideas that are expected to meet their needs. Hawkins et al. (2007) revealed that consumer behavior is a study of individuals, community groups, and organizations in choosing, maintaining, using, and regulating products, services, experiences and ideas to meet needs.

Consumer behavior is part of marketing research activities to combine business and results related to efforts to solve problems and consumer needs (Burnett, 2010). It can be concluded that consumer behavior is a study on how a decision maker (decision units) individuals, groups, or organizations makes purchasing decisions or purchase transactions of a product and consume it. Therefore, the hypothesis is stated below.

H1: Product affect on Purchasing Decisions 


\section{Price and Purchase Decision}

Price is a major factor to consume the products. They play an important role to highlight variations in food consumption, such as fresh fruit and vegetable products relatively low if the prices are relatively high, especially for low-income families. Therefore, the prices and low income families has a negative effect on health food consumption patterns (Sangye, 2013; Turrell, et al., 2003). The food prices also affect on purchasing decisions of health food. Othman, et al. (2013) showed that prices have a significant relationship with purchase decision of health food. Schiffman and Kanuk (2004) defined consumer behavior as the process a person goes through in finding, buying, using, evaluating, and acting after consumption of products, services and ideas to meet their needs. Hawkins (2007) revealed that consumer behavior is a study of individuals, community groups and organizations in choosing, maintaining, using, and managing products, services, experiences, and ideas to meet the needs.

Consumer behavior is part of marketing research activities to combine business and results related to efforts to solve problems and consumer needs (Burnett, 2010). It can be concluded that consumer behavior is a study on how a decision maker (decision units) individuals, groups, or organizations to make purchasing decision or purchase transaction of the product and consume it. Therefore, the hypothesis is stated below.

H2: Prices affect on Purchasing Decisions

\section{METHODOLOGY}

This study uses a quantitative - explanatory approach to examine the cause and effect of product and price on purchasing decisions of health food and examining the dominant effect of the variables. The research locations are five Malang City Subdistricts, namely Blimbing, Klojen, Kedungkandang, Lowokwaru and Sukun Subdistrict. The samples are 384 respondents selected by sampling techniques of Krecjie and Morgan (1970) formulas. Validity Test is used to measure the validity of a questionnaire. Reliability Test is used to measure a questionnaire which is an indicator of a variable. Data normality test is done to see whether a data is normally distributed or not; The heteroskedacity test aims to test whether in the regression model there is an unequal variance from the residuals of one observation to another (Hair, et al., 2010); The third assumption relates to multicollinearity and singularity associated with correlations between predictive variables (Tabachnick \& Fidell, 2007). Data is collected by distributing 5-point Likert scale questionnaires. The dependent variable is the purchase decision of health food variable and independent variables are price and product. Data analysis is SPSS software version 22. The research model framework is shown in the figure 1. 


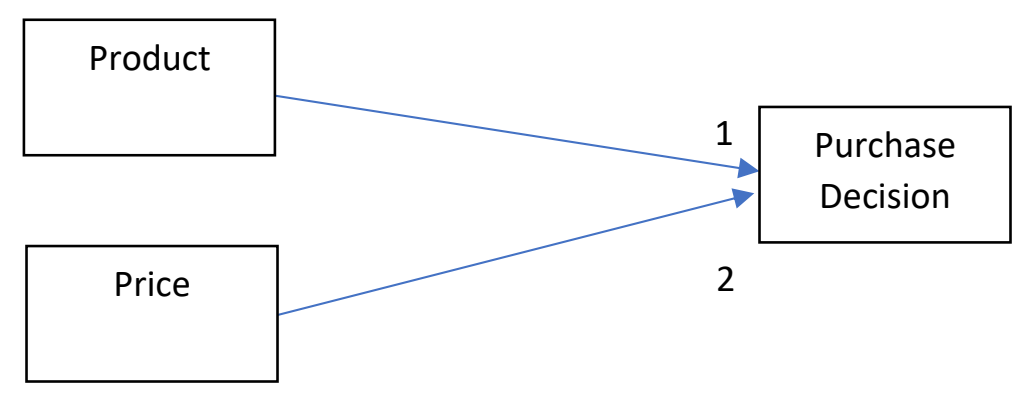

Figure 1. Model Framework

\section{RESEARCH RESULTS}

\section{Descriptive Statistical Analysis}

The respondent descriptions include the demographic distributions. From 384 respondents, $59.1 \%$ were women compared to $40.9 \%$ of men. The age of respondents varied from those aged less than 20 years of $3.9 \% ; 21-30$ years of $20.3 \%$. Total of $31.5 \%$ and $44.3 \%$ for respondents aged 31-40 years and over 40 years. Most respondents are Muslim (95.3\%) and are married (71.6\%). The Javanese were the largest respondents of this study (87.5\%) followed by Madurese and Sumatran at $8.9 \%$ and $1.9 \%$. More than $50 \%$ of respondents have an equivalent level of high school education (60.2\%) and only $3.9 \%$ of respondents have an equivalent post-graduate education. The private sector employment is largest portion of $31.8 \%$, followed by civil servants, others and entrepreneurs $18.5 \% ; 18.5 \%$ and $16.1 \%$, respectively. Table 1 shows that $45.1 \%$ respondents worked for less than 5 years, the respondents who had worked for more than 20 years are $15.9 \%$. The respondent's income level that more than IDR $8,000,000$ is $2.4 \%$.

\section{Validity and Reliability Test}

The validity test results prove that each variable, items analyzed by SPSS version 21, has values above 0.099. It means all that items of each variable are valid. Meanwhile, results of a reliable test prove that each variable has an alpha Cronbach value greater than 0.6 , it means the variables are reliable.

\section{Regression Test}

The classic assumption test was conducted prior regression test. It examines any deviations in terms of normality, heterokedasticity and multicollinearity. Normality test aims to test whether in a regression model, independent variables, dependent variables or both have normal distribution or not. A good regression model is a normal or near normal data distribution. The graphical results obtained from the SPSS program, the normal probability plot test results are obtained as shown at Figure 2 . 

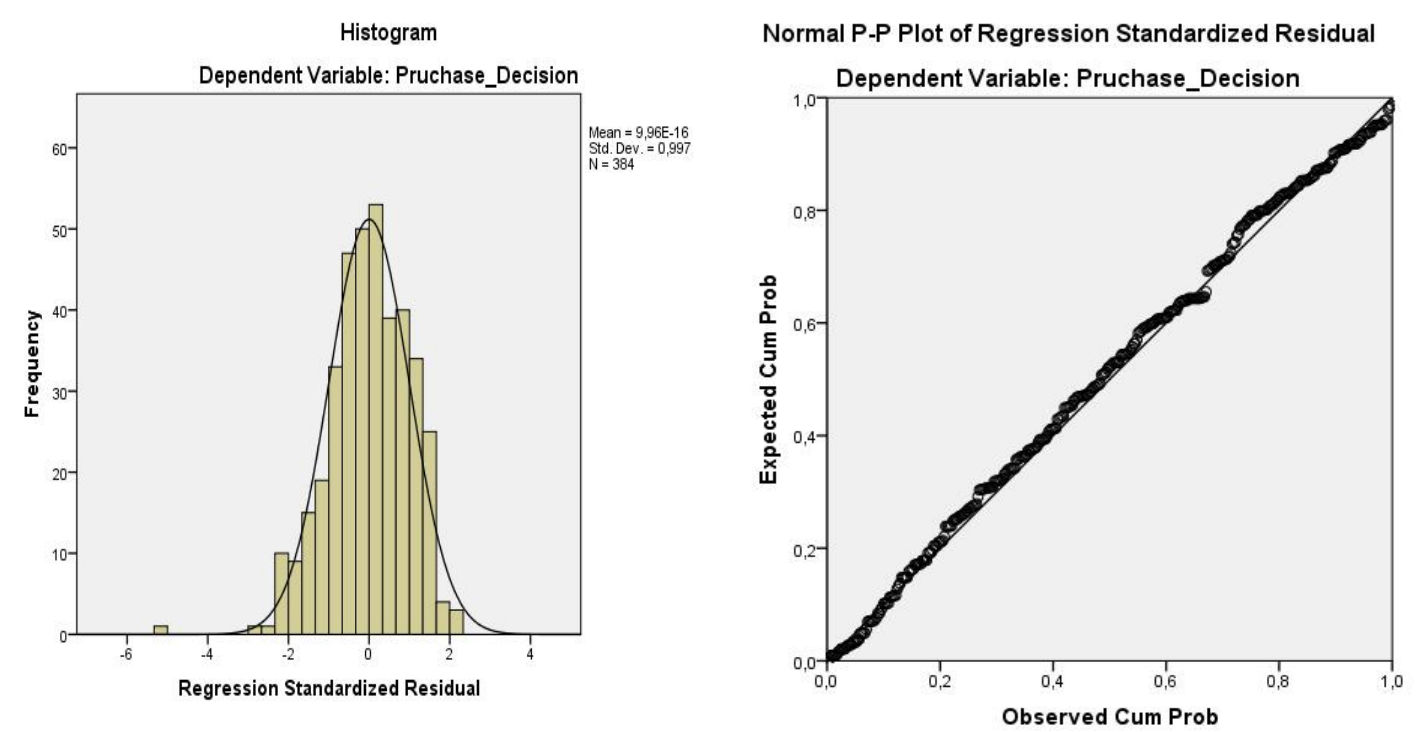

Figure 2. Normal Probality Plotsum

From the graph above shows the distribution of data on the chart scattered around a straight line (not scattered far from the straight line), it can be said that the normality requirements are met. In regression there may be symptoms of heterokedasticity. This test is carried out by the graphical method shown in the figure 3 .

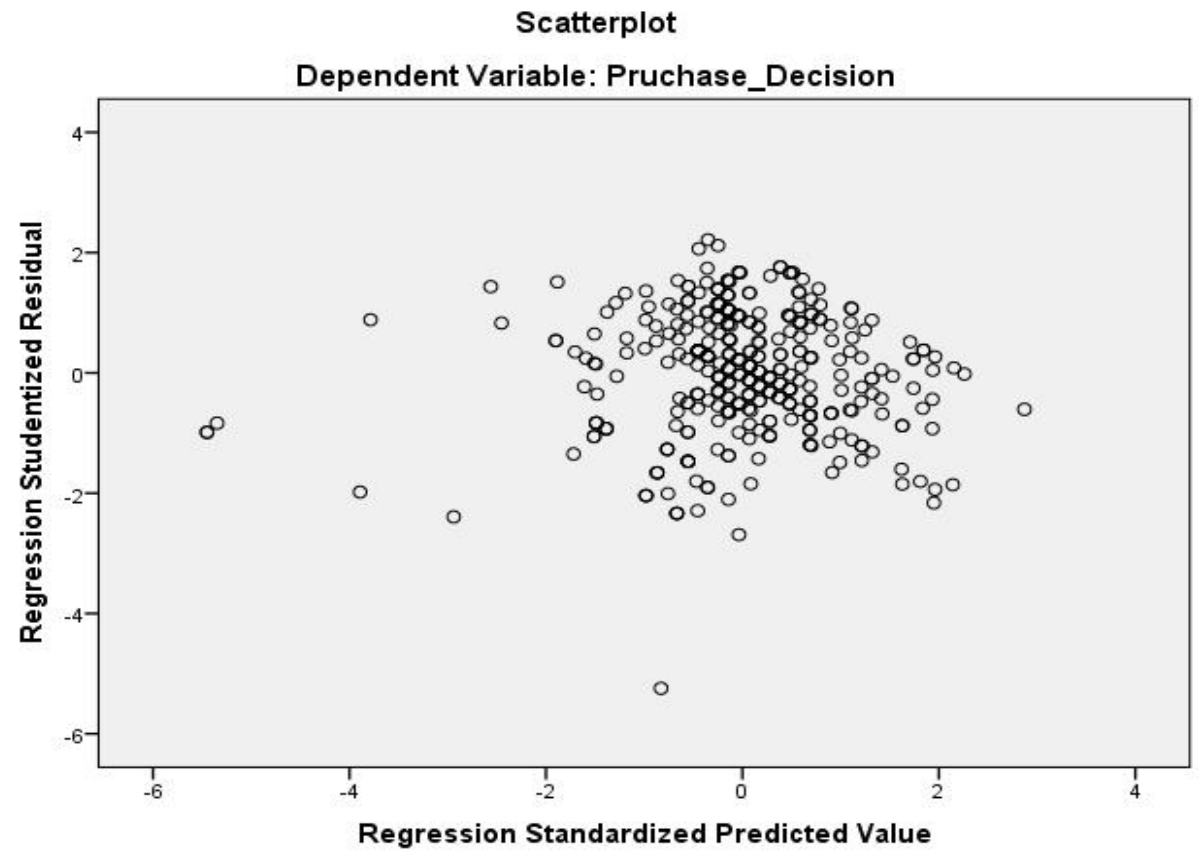

Figure 3. Heterokedastisitas Test 
Heterocedasticity does not occur if the data is scattered around the zero ( 0 on the $Y$ axis) and does not form a pattern or trend of a particular line. From the picture above, it can be seen that the data distribution is around zero points and there does not appear to be a certain pattern of changes in the data distribution. Therefore it can be said that heterokedasticity does not occur.

Multicollinearity Test aims to test whether the regression model found a correlation between independent variables. If there is a correlation, then there is a problem called multicollinearity. A good regression model should not occur correlation between independent variables. Detection of the absence of Multicollinity ie by looking at the amount of VIF (Variance Inflation Factor) and Tolerance (Ghozali, 2006): Has a VIF value $<10$ and has a tolerance number $>0.1$. Referring to the two opinions above, based on the results of the research that has been conducted.

Tabel 1. Multicolinieritas test

\begin{tabular}{llll}
\hline \multicolumn{1}{c}{ Variable } & \multicolumn{2}{c}{ Collienarity Statistics } & Result \\
& Tolerance & VIF & \\
& 0,568 & 1,760 & Non Multicollinearity \\
Product & 0,568 & 1,760 & Non Multicollinearity \\
Price & & & \\
\hline
\end{tabular}

So as discussed in the statistical analysis, there is no multicollinearity for this study. All independent variables have tolerance values less than 0.1 and VIF values less than 10 refer to Table 1.

The results do not show deviations in the classical assumption test. The results of statistical $\mathrm{F}$ test showed that Fcount was 178,933 (sig $\mathrm{F}=0,000$ ). Ftable at $5 \%$ significance level with degrees of freedom 2 and 381 of 36,619. The Fcount> Ftable $(36,619>1,966)$ and Sig $\mathrm{F}<5 \%(0,000<5 \%)$, therefore, $\mathrm{H}_{\mathrm{o}}$ is rejected, which means that product and price have a significant effect on purchasing decisions.

\section{DISCUSSION}

\section{Effect of Products on Purchasing Decisions}

The results showed that higher value of product will increase the purchasing decision. This means that product can affect the purchase decision of health food in Malang. The highest average yield of first item shows that consumers have a purchasing decision in terms of product quality. Second, consumers can decide to buy health food by looking at brand, physical and appearance. This is inseparable from gender, where women are more observant to choose products and purchase decision of health food. Javanese are more numerous, so that it can be known that Javanese consumers can decide to buy familiar health food products in terms of brand, physical and appearance. 
This finding is consistent with Hsieh, Pan, \& Setiono (2004) that products are an important factor in the consumption pattern of health foods. The success of brand image gives consumers the freedom to determine the needs that will increase consumer consumption on brand products. Similarly, Buijzen, Schuurman, \& Bomhof (2008) stated that brand of health food products can improve purchase decision of health food. Important product factors for customers are quality, brand, health \& environmental safety and taste (Indumathi and Dawood, 2016). Heryanto (2015) stated that product affect on purchase decision of goods. Prihatini and Edwar (2016) stated that partially the product affect on purchasing decisions of food. This is inseparable from previous research conducted by Indumathi and Dawood (2016) that product factors are important for customers, followed by quality, brand, health \& environmental safety and taste. Meanwhile, Buijzen, Schuurman, \& Bomhof (2008) showed that brand of health food products can improve food purchasing decisions. There are various factors to effect consumer decision making. They are demographics; socio-economic, cultural status etc. The main factors to affect consumer purchase behavior are age, gender, income and social effect. In addition, in terms of product prices, durability, brand names, product features, after sales services and others may also have affect on decision making (Darshan and Teja, 2019).

\section{Effect of Prices on Purchasing Decisions}

The results showed that higher price can increase value of purchasing decision. This means that price can affect the purchase decision of health food in Malang. Price is also the most dominant variable in the simultaneous test. The highest average product indicates that price applied by company must be economical and affordable to consumers. This is inseparable from consumer income at average of more than 8 million, the purchase decision of health food see the price as the main factor. Consumers feel the prices offered are affordable by their purchasing power, prices offered are in accordance with quality provision of restaurant services, and price comparison is not inferior to other equivalent restaurants (Rachman and Suryoko, 2017).

This finding is consistent with Indahswari, Thaha, \& Syam (2013) that prices have a significant relationship with purchase decision of health food. Price becomes the dominant variable in purchasing decisions (Sudrajad and Andriani, 2015). Prihatini and Edwar (2016) stated that partially the price affect on purchase decision of food. This is supported by Sudrajad and Andriani (2015) that price was the dominant variable in the purchase decision of goods. The results of Sasmaya, Indriani, and Gultom's research (2019) showed that most consumers are Javanese aged 25-35 years and wives with 3-4 household members.

\section{CONCLUSION}

The results of multiple linear regression analysis indicate that product and price simultaneously can increase purchase decision of health food. The products and prices partially also can improve purchase decision of health food. The price variable has a dominant role than the product variable to explain the effect on purchase decision of health food. 


\section{REFERENCES}

Basu, K., \& Wong, M. (2015). Evaluating seasonal food storage and credit programs in east Indonesia. Journal of Development Economics, 115, 200-216. http://doi.org/10.1016/j.jdeveco.2015.02.001

Brandenburg, U. (2011). Indicators for Mapping and Profiling, (August).

Buijzen, M., Schuurman, J., \& Bomhof, E. (2008). Associations between children's television advertising exposure and their food consumption patterns: A household diary-survey study. Appetite, 50(2), 231-239.

Burnett, J. (2010). Introducing Marketing. Swiss: Global Marketing

Darshan, E. M. dan Teja, B. R. (2019). A Study on Customer Purchasing Behaviour on Durable Goods in Kukatpally, Hyderabad. International Journal of Trend in Scientific Research and Development, 3(2),949-952.

Defra. (2015). Food statistics pocketbook 2015. Department for Enviroment Food and Rural Affairs, 15. http://doi.org/10.1016/j.cie.2012.12.008

Dewi, Y. (2013). Studi Deskriptif: Persepsi dan Perilaku Makan Buah dan Sayuran pada Anak Obesitas dan Orang Tua. Calyptra: Jurnal Ilmiah Mahasiswa Universitas Surabaya, 2(1), 1-17.

Ghozali, I. (2006). Aplikasi Analisis Multivariate dengan Program SPSS. (Edisi Ke 4). Semarang: Badan Penerbit Universitas Diponegoro

Hair, J. F., Black, W. C., Babin, B. J., Anderson, R. E., \& Tatham, R. L. (2010). Multivariate data analysis. Prentice Hall.

Hawkins, Dell. Best, Roger J. dan Coney, Kenneth A. (2007). Consumer Behavior.NewYork:TheMcGraw-HillCompanies, Inc.

Heryanto, I. (2015). Analisis Pengaruh Produk, Harga, Distribusi, Dan Promosi Terhadap Keputusan Pembelian Serta Implikasinya Pada Kepuasan Pelanggan. Jurnal Ekonomi, Bisnis \& Entrepreneurship, 9(2), 80-101. Issn 2443-2121.

Hsieh, M. H., Pan, S. L., \& Setiono, R. (2004). Product-, corporate-, and country-image dimensions and purchase behavior: A multicountry analysis. Journal of the Academy of Marketing Science, 32(3), 251-270.

Indahswari, L., Thaha, A. R., \& Syam, A. (2013). Hubungan Pola Konsumsi dengan Kejadian Anemia pada Wanita Prakonsepsi di Kecamatan Ujung Tanah dan Kecamatan Biringkanaya Kota Makassar. Repository Unhas, 1-11.

Indumathi, N., \& Dawood, D. (2016). Impact of marketing mix on consumer buying behavior in organic. International Journal of Research in Finance and Marketing, 6(10), 43-54.

Krejcie, R. V, \& Morgan, D. W. (1970). Determining Sample Size for Research Activities 
Robert. Educational and Psychological Measurement, 38(1), 607-610. http://doi.org/10.1177/001316447003000308

Lovelock, C, dan John Wirtz. (2011). Pemasaran Jasa Perspektif. edisi 7. Jakarta : Erlangga

Muzondo, N. (2016). Modelling consumer behaviour conceptually through the seven Ps of marketing: A revised theoretical generic consumer stimulus-response model. University of Zimbabwe Business Review, 4(1),89-107.

Othman, K. I., Ab Karim, M. S., Karim, R., Adzhan, N. M., \& Halim, N. A. (2013). Consumption pattern on fruits and vegetables among adults: a case of Malaysia. Academic Journal of Interdisciplinary Studies, 2(8), 424.

Prihatini, C. W. dan Edwar, M. (2016). Pengaruh Kualitas Produk Dan Harga Terhadap Keputusan Pembelian Di Warung Ikan Bakar Seafood Genteng Besar. Skripsi. Unesa.

Rachman, D. A., \& Suryoko, S. (2017). Pengaruh Kualitas Pelayanan dan Harga terhadap Keputusan Pembelian (Studi Kasus pada Rumah Makan Wajan Mas Kudus). Jurnal Ilmu Administrasi Bisnis, 6(4), 136-143.

Roemling, C., \& Qaim, M. (2013). Dual burden households and intra-household nutritional inequality in Indonesia. Economics and Human Biology, 11(4), 563-573. http://doi.org/10.1016/j.ehb.2013.07.001

Sangye, A. M. (2013). Barriers to Consuming Healthy Food and the Role of Food Pantries in Improving Diets on Low Income Families. Thesis. Wright State University, Dayton, Ohio.

Santoso, A. (2011). Serat Pangan (Dietary Fiber) dan Manfaatnya Bagi Kesehatan. Magistra, (75), 35-40.

Sari, Y. D., Prihartini, S., \& Brantas, K. (2014). Asupan serat makanan dan kadar kolesterol-LDL... (Sari YD; dkk). Penelitian Gizi Dan Makanan, 37(1), 51-58.

Sasmaya, I., Indriani, Y., dan Gultom, D.T (2019). Perilaku Konsumen Dalam Pembelian Sayuran Di Pasar Tradisional Kota Metro. Jurnal Ilmu-Ilmu Agribisnis; Vol 7, No 3 (2019); 330-337; 2337-7070.

Schiffman, GL dan Kanuk. (2004). Perilaku Konsumen. Edisi Ketujuh. PT. Jakarta: Indeks Grup Gramedia.

Sidjabat, C. A. (2015). Development of Indonesian Food and Beverages Industry. Ina Magazine, 14-20.

Studies, G. F. (2015). Agriculture - Nutrition Pathways, 1-19.

Sudrajad, A. B. dan Andriani, D. R. (2015). Pengaruh Atribut Produk Terhadap Keputusan Konsumen Dalam Pembelian Produk Abon Jamur Tiram Di Perusahaan Ailanifood Kota Malang Jawa Timur. Habitat, 26(2), 71-79.

Tabachnick, B. G., \& Fidell, L. S. (2007). Using multivariate statistics. Allyn \& 
Bacon/Pearson Education.

Tangkudung, M., Kadir, S., \& Pateda, S. M. (2013). Perubahan Kadar Asam Lemak Bebas Pada Minyak Goreng Curah, Minyak Jagung Dan Minyak Zaitun Setelah Proses Penggorengan Berulang. Universitas Negeri Gorontalo, 1-12.

Turrell, G., Patterson, C., Oldenburg, B., Gould, T., \& Roy, M. A. (2003). The socioeconomic patterning of survey participation and non-response error in a multilevel study of food purchasing behaviour: area-and individual-level characteristics. Public health nutrition, 6(2), 181-189.

Umberger, W. J., He, X., Minot, N., \& Toiba, H. (2015). Examining the relationship between the use of supermarkets and over-nutrition in Indonesia. American Journal of Agricultural Economics, 97(2), 510-525. http://doi.org/10.1093/ajae/aau111

Waage, J., Hawkes, C., Turner, R., Ferguson, E., Johnston, D., Shankar, B., Haseen, F. (2013). Current and planned research on agriculture for improved nutrition: A mapping and a gap analysis. Proceedings of the NutritionSociety, 72(May), E317. http://doi.org/http://dx.doi.org/10.1017/S0029665113003509

Widarjono, A. (2012). Food And Nutrient Demand In Indonesia. Dissertation. Oklahoma State University. 